\title{
Prospective trial of intraoperative mitomycin C in the treatment of primary pterygium
}

\author{
Juan Cano-Parra, Manuel Diaz-Llopis, Miguel J Maldonado, Emilio Vila, José L Menezo
}

\begin{abstract}
Aims-A prospective, randomised, double blind, placebo controlled study of intraoperative mitomycin $C$ as adjunctive treatment of primary pterygium was conducted.

Methods-A total of 66 eyes of 54 patients with primary pterygium were treated with excision, with or without a single intraoperative application of mitomycin C $(0.1 \mathrm{mg} / \mathrm{ml}$ for 5 minutes) to evaluate the efficacy and toxicity of this adjunctive treatment. The mean follow up was $14 \cdot 1$ months (range 12-23 months).

Results-Of the 36 eyes that underwent simple excision, $14(38 \cdot 8 \%)$ exhibited recurrences whereas only one of 30 eyes $(3.33 \%)$ treated with excision and intraoperative application of mitomycin $\mathrm{C}$ had recurrence $(p=0 \cdot 0006)$. Neither serious ocular complications nor systemic toxicity were noted in the mitomycin $C$ treated group.

Conclusion-Intraoperative mitomycin C appears to be an effective and safe adjunctive treatment of primary pterygium.

(Br f Ophthalmol 1995; 79: 439-441)
\end{abstract}

Pterygium is a triangular sheet of fibrovascular tissue that invades the clear cornea from the bulbar conjunctiva, and has a high recurrence rate after simple excision ${ }^{1-3}$ unless any adjunctive treatment is applied. The use of postoperative $\beta$ irradiation renders a lower incidence of recurrence but may lead to complications such as scleral ulceration, infection, and cataract. ${ }^{4}$ Other effective treatments such as the use of topical thiotepa can cause depigmentation of the lids, ${ }^{56}$ and postoperative topical mitomycin $\mathrm{C}$ has been associated with serious ocular complications. ${ }^{7}$

We studied the efficacy and toxicity of intraoperative mitomycin $\mathrm{C}$ in the treatment of primary pterygium in a randomised, prospective, double blind, placebo controlled study comparing standard excision with excision and a single intraoperative application of mitomycin C.

Ophthalmology of La

Fe University Hospital,

Valencia, Spain

J Cano-Parra

M Diaz-Llopis

$M$ J Maldonado

E Vila

J L Menezo

Correspondence to Juan Cano-Parra, $\mathrm{MD}$ Rambla Prim 139, Escalera Z, 5o 2a, 08020 Barcelona, Spain

Accepted for publication 10 January 1995

A total of 66 consecutive primary pterygia were September 1992 and August 1993. A complete ocular examination, photographic documentation of the pterygium, and haematological examination (complete cell counts with differential, sedimentation rate, electrolytes, prothrombin time, and prothrombin thromboplastin time) were performed for each patient. The inclusion criteria were (1) age older than 20 years, (2) primary pterygium which invaded more than $2 \mathrm{~mm}$ into the cornea. Exclusion criteria were (1) external ocular diseases such as Sjögren syndrome and ocular rosacea, (2) abnormal cell counts. The protocol was approved by the ethics and clinical trials committee of $\mathrm{La} \mathrm{Fe}$ University Hospital. Informed consent was obtained from all patients.

All the surgical excisions of the pterygium were performed on an outpatient basis by two different surgeons (MJM, EV) using the same technique under an operating microscope. The surgical technique was as follows:

(1) conjunctival topical anaesthesia with $0 \cdot 1 \%$ tetracaine chlorhydrate and $0 \cdot 1 \%$ oxybuprocaine chlorhydrate eyedrops twice before entering the operating theatre,

(2) placement of rigid lid speculum,

(3) subconjunctival injection of $0.5 \mathrm{ml}$ of $0.4 \%$ mepivacaine chlorhydrate into the body of the pterygium with a 25 gauge needle,

(4) dissection of pterygium from cornea with Baird Parker No 15 surgical blade with partial superficial keratectomy,

(5) dissection with spring action scissors onto conjunctiva and Tenon's capsule,

(6) complete resection leaving $3 \mathrm{~mm}$ or more of bare sclera exposed with occasional light bipolar cautery of the bleeding vessels,

(7) at this moment, patients were randomised in a masked fashion to receive a 5 minute scleral application of a $4 \times 5 \mathrm{~mm}$ fragment of surgical sponge ( $k$ sponge No $K$ 20-5000, Katena Products Inc, Denville, USA) soaked in a solution of $0.1 \mathrm{mg} / \mathrm{ml}$ of mitomycin $\mathrm{C}$ or in distilled water for eyes in the control group,

(8) the site was irrigated copiously with $20 \mathrm{ml}$ of a saline solution after removal of the sponge,

(9) no conjunctival sutures were used,

(10) instillation of topical eyedrops of $0 \cdot 1 \%$ dexamethasone and gentamicin ointment followed by eye patching. Oral analgesics (paracetamol every 8 hours) were given to relieve postoperative pain.

Mitomycin C was present in a blue-violet crystalline powder that was reconstituted and diluted in sterile water just before surgery.

All the pterygia were evaluated on postsurgically excised in 54 patients between patient's treatment status. All patients had repeat haematological examination on postoperative day 7 , and periodic ocular photographic documentation was obtained. A total of 12 patients with bilateral pterygium were 
Table 1 Demographic and surgical data of 54 patients with primary pterygium

\begin{tabular}{llllll}
\hline $\begin{array}{l}\text { Treatment } \\
\text { group }\end{array}$ & $\begin{array}{l}\text { No of } \\
\text { patients }\end{array}$ & $\begin{array}{l}\text { Mean age (SD) } \\
\text { at treatment } \\
\text { (years) }\end{array}$ & $\begin{array}{l}\text { No of } \\
\text { eyes }\end{array}$ & $\begin{array}{l}\text { Sex } \\
\text { (M:F) }\end{array}$ & $\begin{array}{l}\text { No of eyes with } \\
\text { recurrence } \\
\text { (\%) }\end{array}$ \\
\hline Excision & 29 & $50(6)$ & 36 & $22: 7$ & $14(38 \cdot 8) \dagger$ \\
Excision+mitomycin C & 25 & $54(3)$ & 30 & $20: 5$ & $1(3.33) \dagger$ \\
Total & 54 & $51 \cdot 8(5)$ & 66 & $42: 12$ & 15 \\
\hline
\end{tabular}

* 12 patients with bilateral pterygium were treated by different procedures. Each eye of these patients was entered into each group. $t p=0.0006, \chi^{2}$ test.

treated with a different procedure in each eye. The data on these patients were entered into each group, according to the treatment regimen. Patients were excluded if they did not complete the minimum follow up period of 12 months. The number of eyes defaulting from complete follow up in the mitomycin $\mathrm{C}$ treated group was three, whereas in the control group it was four (no statistical differences were found between the defaulting eyes in the two groups).

Recurrence was defined as the postoperative regrowth of fibrovascular tissue that invaded the cornea. Postsurgical conjunctival granulomas were treated with topical dexamethasone $0 \cdot 1 \%$ for 2 to 4 weeks. Statistical analysis of the recurrence rate of pterygium in both treatment modalities was determined by $\chi^{2}$ test.

\section{Results}

The sex distribution of these 54 patients was 42 males and 12 females and the mean age was $51 \cdot 8$ (range 25 to 71 ) years. All the patients were white and all the pterygia were in nasal localisation. No sex, age, or surgeon differences were found between the two groups. In the control group, 14 of 36 eyes $(38.8 \%)$ had recurrences after a mean follow up of $14 \cdot 1$ months (range 12-23 months) while in the mitomycin C group, only one of 30 eyes $(3.33 \%)$ exhibited recurrence after the same follow up period $(p=0.0006)$ (Table 1). A feature in our study was that of the 12 patients who underwent bilateral surgical excision of pterigia (a randomised eye with intraoperative mitomycin $\mathrm{C}$ and the other without), all the recurrences (four eyes) were noted in the eyes that did not receive this adjunctive treatment.

Table 2 summarises the postoperative complications of these patients. In the mitomycin $\mathrm{C}$ group, conjunctival wound healing was delayed in all the eyes by 7-15 days. Conjunctival granulomas were noted in five eyes $(16.6 \%)$ but only one eye $(3.33 \%)$ progressed to recurrent pterygium causing high astigmatism $(3.5 \mathrm{D}) 1$ month after surgery. In the first week a moderate superficial punctate keratitis was observed in eight of the 30 mitomycin treated eyes $(26.6 \%)$. However, none of

Table 2 Postoperative complications

\begin{tabular}{llc}
\hline Complication & $\begin{array}{l}\text { Mitomycin } C \\
\text { treated eyes }\end{array}$ & $\begin{array}{l}\text { Control } \\
\text { eyes }\end{array}$ \\
\hline Delayed wound healing (1-2 weeks) & 30 & 0 \\
Conjunctival granuloma & 5 & 14 \\
Astigmatism (+2 D) & 1 & 12 \\
Superficial punctate keratitis & 8 & 2 \\
Anterior chamber reaction & 2 & 0 \\
\hline
\end{tabular}

these patients complained of severe discomfort. A mild anterior chamber reaction developed in the first postoperative day in two mitomycin C treated eyes (6.6\%). Neither conjunctival nor corneal infection was observed in this group. All the mitomycin C treated eyes showed characteristic areas of sclera with a relatively avascular surface, however, we did not observe any scleral thinning of these eyes during the follow up. Neither significant haematological changes nor systemic toxicity was recognised in any of the treated patients with intraoperative mitomycin C. These eyes are being followed up further to study possible long term complications.

\section{Discussion}

Primary pterygium is one of the most common corneal disorders seen in our community because the inhabitants have a high exposure to ultraviolet light. This causative factor has been established as the most important risk factor in its development. ${ }^{8}$ Excision with the bare sclera technique as described by Ombrain ${ }^{9}$ is the most widely used procedure of treatment of pterygium. Nevertheless this technique is accompanied by a recurrence rate of $30-50 \% .{ }^{10}$ Different adjunctive treatments to excision of the pterygium have been shown to diminish the recurrence rate; however, variable complications have been reported. ${ }^{11}$ The use of conjunctival autograft also has a recurrence rate between $5 \cdot 3 \%$ and $21 \% .1213$ The recurrence of pterygium appears not to be associated with ultraviolet light exposure and would be due to an accelerated fibroblastic proliferation produced by the trauma of operation in the same way as the production of keloid tissue. ${ }^{14}$

Mitomycin $\mathrm{C}$ is an antineoplastic antibiotic agent isolated from the fermentation filtrate of Streptomyces caespitosus. Its action is similar to those of alkylating agents, alkylates and crosslinks DNA and, in addition, may generate superoxide and hydroxyl radicals in solution. It also inhibits DNA synthesis and RNA and protein synthesis. ${ }^{15}$ These combined effects may result in long term effects on cellular proliferation.

In a previous experimental study of the effects of mitomycin $\mathrm{C}$ on cultured rabbit subconjunctival fibroblasts, the authors found that its antiproliferative effect is both dose and time dependent. ${ }^{16}$ Other in vitro studies have shown that the effect of 5 minute exposure with mitomycin $\mathrm{C}$ at a concentration of $0.1 \mathrm{mg} / \mathrm{ml}$ to human Tenon's capsule fibroblasts results in a significant long term inhibition of fibroblast proliferation. At this dose, the number of cells did not increase more than 2.5 times to the density at day 0 during a 36 day period of the experiment, despite stimulation throughout this period with $10 \%$ fetal bovine serum. In contrast, at a concentration of $1 \mathrm{mg} / \mathrm{ml}$ more than $65 \%$ of the cells died. ${ }^{17}$

However, there are limitations in applying results of in vitro studies to the in vivo situation. The action of a drug over a monolayer of cells with relatively small amounts of 
extracellular matrix, and where most of the cells are proliferating may be different from the in vivo situation where cells are surrounded by connective tissue, which may impede drug penetration. Nevertheless, at the time of conjunctival surgery there are several growth factors, such as platelet derived growth factor (PDGF), that are released and might play an important role in pterygium recurrence. If the process is impaired even at this early stage, the ability of the fibroblast to proliferate as well as the capillaries to grow may be impaired.

The use of mitomycin $C$ eyedrops in the postoperative period of pterygium surgery, in both doses, 0.2 and $0.4 \mathrm{mg} / \mathrm{ml}$, four times daily for 5-15 days has been effective in reducing the recurrence rate of pterygium between $0 \%-9 \% .{ }^{18-20}$ However, in a recent report this postoperative treatment has been related to serious ocular complications such as secondary glaucoma, corneal oedema, corneal perforation, iritis, sudden onset mature cataract, and scleral calcification. ${ }^{7}$ In contrast, no serious complications have been noted in another study ${ }^{21}$ with the postoperative use of $0.1 \mathrm{mg} / \mathrm{ml}$ mitomycin $\mathrm{C}$ twice daily for 5 days (with a mean follow up period of 15.3 months) or in the intraoperative mitomycin $\mathrm{C}$ treated eyes of our current study. A common element in toxicity with mitomycin $\mathrm{C}$ is a relatively large cumulative dose. ${ }^{722}$ Therefore, we consider that a single intraoperative exposure to mitomycin $\mathrm{C}$ would reduce the complication rate of mitomycin $C$ eyedrop regimen.

Although serious complications with low concentrations of mitomycin $\mathrm{C}$ are rare, we noted in our study only minor complications. Delayed epithelial closure as a side effect of mitomycin C may predispose to postoperative infectious scleritis and endophthalmitis, particularly in tropical countries. None of the complications of mitomycin $\mathrm{C}$ treated eyes presented in Table 2 significantly troubled the patients. Moreover, conjunctival granulomas were found to be less frequent among the mitomycin $\mathrm{C}$ group than among the control group.

Recurrence of pterygium commonly occurs within 6 months after the initial surgery ${ }^{23}$ and the minimum follow up in our study has been 12 months. However, there are late complications such as scleromalacia related to the use of topical mitomycin C. ${ }^{24}$ Therefore, it is necessary to continue to assess the eyes treated with mitomycin $\mathrm{C}$ after this period.

We have shown that the single intraoperative exposure to mitomycin $\mathrm{C}(0.1 \mathrm{mg} / \mathrm{ml})$ reduces the recurrence rate of primary pterygium without serious complications over a mean follow up of $14 \cdot 1$ months. We suggest that the single intraoperative exposure of mitomycin C appears to be a safe, simple, effective, and useful form of adjunctive therapy to the surgical treatment of the primary pterygium.

The authors have no financial interest in this drug.

1 Duke-Elder WS. Diseases of the outer eye. Conjunctiva. In: Duke-Elder WS, ed. System of ophthalmology. Vol 8, Part 1. London: Henry Kimpton, 1965: 573-83.

2 Small RG. Pterygium. In: Hornblass A, ed. Oculoplastic, orbital and reconstructive surgery. Vol 1. Baltimore: orbital and reconstructive surgery.
Williams and Wilkins, 1988: 693-703.

3 Pico G. Surgery for pterygium. In: Smith BC, Della Rocca RC, Nesi FA, Lishman RD, eds. Ophthalmic plastic and reconstructive surgery. Vol 2. St Louis: Mosby, 1987: 1416-24.

4 Tarr $\mathrm{KH}$, Constable IJ. Late complications of pterygium treatment. $\mathrm{Br} \mathcal{F}$ Ophthalmol 1980; 64: 496.

5 Meacham CT. Triethylene thiophosphoramide in the prevention of pterygium recurrence. Am $\mathcal{f}$ Ophthalmol prevention of pte

6 Rock RL. Inhibition of corneal vascularization by triethylene thiophosphoramide. Arch Ophthalmol 1963; 69: 330.

7 Rubinfeld RS, Pfister RR, Stein RM, Foster CS, Martin NF, Stoleru S, et al. Serious complications of topical mitomycin-C after pterygium surgery. Ophthalmology 1992; 99: 1647-54.

8 Mackenzie FD, Hirst LW, Battistutta D, Green A. Risk analysis in the development of pterygia. Ophthalmology 1992; 99: 1056-61.

9 Ombrain A. The surgical treatment of pterygium. $\mathrm{Br} \mathcal{F}$ Ophthalmol 1948; 32: 65.

10 Inster MS, Caldwell DR. Peripheral diseases (Terrien's and recurrent pterygium). In: Brightbill FS, ed. Corneal surgery theory, technique and tissue. St Louis: Mosby, 1986: 387-95.

11 Flament J, Speeg-Schatz CL, Weber M. Etat actuel du traitement du ptérygion. $\mathcal{F}$ Fr Ophtalmol 1993; 16: 401-10.

12 Kenyon $\mathrm{KR}$, Wagoner MD, Hettinger ME. Conjunctival autograft transplantation for advanced and recurrent pterygium. Ophthalmology 1985; 92: 1461-70.

13 Lewallen S. A randomized trial of conjunctival autografting for pterygium in the Tropics. Ophthalmology 1989; 96: $1612-4$.

14 Cameron ME. Histology of pterygium: an electron microscopic study. Br f Ophthalmol 1983; 67: 604-8.

15 Glaubiger D, Ramu A. Antitumor antibiotics. In: Chabner BA, ed. Pharmacologic principles of cancer treatment. Philadelphia: WB Saunders, 1982: 407-10.

16 Yamamoto T, Varani J, Soong HK, Lichter PR. Effects of 5 -fluorouracil and mitomycin-C on cultured rabbit subconjunctival fibroblasts. Ophthalmology 1990; 97: 1204-10.

17 Khaw PT, Sherwood MB, Mackay SLD, Rossi MJ, Schultz G. Five-minute treatments with fluorouracil, floxuridine, and mitomycin have long-term effects on human Tenon's capsule fibroblasts. Arch Ophthalmol 1992; 110: 1150-4.

18 Hayasaka S, Noda S, Yamamoto Y, Setogawa T. Postoperative instillation of low-dose mitomycin C in the treatment of primary pterygium. Am $\mathcal{F}$ Ophthalmol 1988; 106: 715-8.

19 Singh G, Wilson MR, Foster CS. Mitomycin eye drops as treatment for pterygium. Ophthalmology 1988; 95: 813-21.

20 Mahar PS, Nwokora GE. Role of mitomycin C in pterygium surgery. Br F Ophthalmol 1993; 77: 433-5.

21 Frucht-Pery J, Ilsar $M$. The use of low-dose mitomycin-C for prevention of recurrent pterygium. Ophthalmology for prevention of

22 Gillman AG, Rall TW, Nies AS, Taylor P, eds. In: Goodman and Gilman's. The pharmacological basis of therapeutics. 8th ed. New York: Pergamon Press, 1990: 1247-8.

23 Pico G. Recurrent pterygium in corneal and external disease of the eye. In: Polack $\mathrm{F}$, ed. First InterAmerican Symposium. Springfield. IL, 1970: 279-84.

24 Yamanouchi U, Takaku I, Tsuda N, Kajiwara Y, Mine M, Ueno Y, et al. Scleromalacia presumably due to mitomycin $\mathrm{C}$ instillation after pterygium excision. $\mathfrak{f p}_{p} \mathcal{f} \mathrm{Clin}$ Ophthalmol 1979; 33: 139-44. 